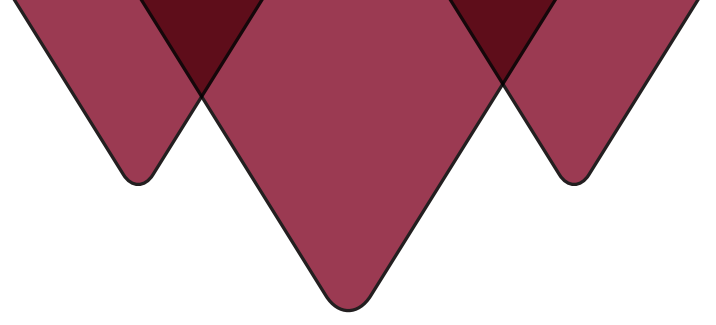

\title{
Critical Library Performativity: Toward Progressive Change in Academic Library Management and Organizations
}

\author{
Danya Leebaw \\ University of Minnesota Libraries
}

\begin{abstract}
Can library managers be \#critlib? Do articles and conversations about critical theory really lead to progressive changes in library organizations and management? In this article, I introduce "critical performativity," the latest wave of critical management studies (CMS), and apply its framework to academic library management and organizations. CMS scholars deploy critical theory to denaturalize taken-for-granted methods and goals of mainstream management studies and practice. Critical performativity is an offshoot of CMS that seeks to bridge the gap between critical theory in the academy and authentic engagement with practicing managers. After introducing CMS and critical performativity, I consider critical performativity's implications for critical library scholars, workers, and managers. Unlike our CMS scholarly counterparts, most librarians who align with critical perspectives are also ourselves practitioners. We occupy a dissonant position of recognizing irrational practices and norms in our libraries while still working within them. Critical performativity offers a useful framing and thought-provoking ideas for integrating our critical leanings into our daily practice as we work to achieve change.
\end{abstract}

Keywords: critical librarianship · critical management studies · critical performativity

\section{RÉSUMÉ}

Etre \#critlib, est-ce pour les gestionnaires de bibliothèques? Les articles et les conversations sur la théorie critique conduisent-ils vraiment à des changements progressifs dans l'organisation et la gestion des bibliothèques? Les études critiques de gestion (ECG), un sous-domaine des études de gestion, appellent à la dénaturalisation des pratiques de gestion allant de soi, à la réflexivité dans les méthodes et aux objectifs antiperformatifs. Cependant, craignant que les ECG ne soient trop idéalistes et inefficaces, certains de ses adhérents ont proposé une construction théorique qu'ils appellent "performativitécritique» (PC). La PC vise à établir un pont entre la théorie critique et l'engagement authentique avec les gestionnaires en exercice. Cet article présente et résume la recherche concernant la PC, puis examine les leçons que la PC peut offrir aux érudits, au personnel et aux gestionnaires de la pratique documentaire critique. Contrairement à nos homologues universitaires des ECG, la plupart des bibliothécaires qui souscrivent aux perspectives critiques 
sont aussi praticiennes et praticiens. Pour nous, la PC propose un cadre utile et des idées qui incitent à la réflexion pour intégrer nos penchants critiques et notre pratique quotidienne afin d'œuvrer pour un changement réalisable.

Mots-clés : bibliothéconomie critique ·études critiques de gestion · performativitécritique

$\mathbf{I}_{\mathrm{N}}$ $\mathrm{N}$ recent decades, scholars who question mainstream practices have emerged in management studies as well as librarianship. In management studies, a subfield that has come to be called "critical management studies" (CMS) uses critical theory to imagine alternatives to mainstream management scholarship and practice. This critical approach to management scholarship has been characterized as adhering to three main principles: reflexivity of position and methods, anti-performativity, and denaturalization (Fournier and Grey 2000). A main thrust of CMS scholarship is to call into question management practices and organizational structures that are taken for granted as rational and natural. In libraries, "critical librarianship" is a similarly loosely affiliated movement of scholars and library workers who often turn to critical theory to question rationalist, positivist assumptions in mainstream library practices (Schroeder and Hollister 20I4). Lessons from CMS can help us "see the irrational in the seemingly rational" practices that we take for granted in academic library organizations and management, and also bring the topic of management to the critical librarianship conversation (Nicholson, Schmidt, and Sloniowski 20I9; Leebaw 20I9).

As CMS has matured, its own adherents have worried that the lack of attention to performativity has limited the potential impact of their research. Performativity in CMS is typically understood to mean management study and practice that has "performative intent": its unquestioned purpose is to maximize efficient productivity and "involves inscribing knowledge within means-end calculation" (Fournier and Grey 2000, I7). Recently, some CMS-aligned scholars have suggested that in its efforts to be anti-performative too much of CMS scholarship winds up being impractical, elitist, cynical, and ultimately fails to meet its purported goal of worker emancipation. Instead, these internal critics propose that CMS should evolve to embrace "critical performativity," a redefinition of the concept of performativity that provides a means for CMS principles to be authentically promoted and enacted in practice. According to Spicer, Alvesson, and Kärreman, "Critical performativity involves active and subversive intervention into managerial discourses and practices. This is achieved through affirmation, care, pragmatism, engagement with potentialities, and a normative orientation" (2009, 538). 
Critical performativity provides a path forward for those who are critical of mainstream library management practices but want to enact progressive change from within these structures at the same time. Indeed, critical performativity is arguably more relevant, useful, and rational than CMS overall when it comes to the academic library context. Unlike CMS scholars, who sit at a remove from the practices they critique and lack clear influence, critical librarians usually wear both scholar and practitioner hats alike. Library managers who embrace critical perspectives are more likely than CMS scholars to have grappled with questions like how to participate in mainstream managerial structures that they themselves question and what kinds of progressive change are possible within their own organizations. Several areas of librarianship have already developed as areas of focus for critical praxis, in particular cataloguing and classification, information literacy, and library scholarship (Schroeder and Hollister 20I4). Perhaps critical performativity points the way toward a "critical library performativity," a set of theories and practices by which critically-minded library managers can integrate theory and practice-and disentangle the rational from the irrational-in their libraries and daily work.

With these ideas in mind, this paper offers an inquiry into critical performativity and its implications for academic library organization and management. Critical performativity has not been adopted wholesale by CMS, but rather is highly contested within the CMS field. Instead of presenting one perspective or interpretation of critical performativity as correct or more deserving of focus, the first half of this paper summarizes a range of the interpretive literature and intentionally leaves the debates unresolved. I am not a CMS scholar but survey its literature in order to consider its core proposals for librarianship. By encountering the various and conflicting arguments that comprise the critical performativity literature to date, readers will deepen their own understanding and arrive at their own conclusions. Critical performativity should be understood as an extension, not a replacement, of CMS: a set of proposed critical, discursive interventions into management and organizational practices. In the second half of my paper, I work through the potential application of several suggested critical performativity interventions to the academic library context. Even though adherents of critical performativity disagree about the extent to which one can critique a system but still operate within it, criticallyminded library managers are already in this awkward position. Rather than abandon our critical inclinations, or quit our jobs, I believe critical performativity offers us a potential third option: to critique the irrational in our libraries and promote change from within. 


\section{Critical Management Studies}

Critical management studies critiques the theories, methods, and overall purpose of management studies, its parent field. The unstated goal of mainstream management studies is to help managers improve their return on investment and organize their workforces toward their own objectives. Management is studied as a science and managers are understood as rational actors fulfilling a technical function (Alvesson and Willmott I992, I). Critical management studies instead uses critical theory to problematize and contextualize management within broader social questions and a systemic framing of power (Alvesson and Willmott 2012). Labour process theory, which enlists Marxist concepts of power and control in organizational studies, is often considered to be the first wave of critical management studies (Spicer, Alvesson, and Kärreman 2016). The second wave is distinguished by a wide-ranging deployment of Frankfurt School post-structuralist theory into management studies (Spicer, Alvesson, and Kärreman 20I6). Overall, CMS is "theoretically fragmented" but could be said to bounded together its proponents' antagonism toward mainstream management studies (Parker and Parker 20I7, I368).

In recent decades, CMS scholarship has come to be understood as having three definitional characteristics: denaturalization of taken-for-granted management and organizational practices, anti-performative intent, and reflexivity (Fournier and Grey 2000). CMS scholarship aims to challenge management practices and theories that are currently taken for granted, such as the top-down power of senior leaders and the emphasis on productivity as the most important goal. CMS scholars also question what they see as the positivist performative intent underlying mainstream management theory; management studies' primary purpose is to improve the performance of managers and organizations as would be reflected in quantifiable outputs (e.g., return on investment). Unlike mainstream management studies, CMS aims to be reflexive by being transparent about its methods and engaging in selfcritique. CMS's imperative to denaturalize and "derationalize" taken-for-granted management and organizational practices is highly relevant to the theme of this special issue.

\section{Critical Performativity}

In recent years, critical management studies scholars have begun to surface what they see as foundational problems within their field that contradict its stated goals. For instance, they worry that CMS is myopically focused on negative critique at the expense of engaging in potentialities for organizations. "What appears to link CMS academics is that they are against things and this sense of antagonism is largely what has held CMS together," write Parker and Parker (20I7, I368). Spicer, 
Alvesson, and Kärreman accuse CMS of being mostly about esoteric theories and almost entirely dissociated from management practice (2009). They also claim that CMS has not done enough to assert a normative claim about what it wants to see in organizations and management (2009). Other critics believe CMS scholars should care more about finding allies within organizations and identifying emancipatory opportunities for employees, even on a micro scale, such as spaces for freedom, more self-determination, and bottom-up initiatives (Fleming and Banerjee 2016; Spicer, Alvesson, and Kärreman 2009, 553; Wickert and Schaefer 2015). Another complaint is that CMS scholars are unreflexive about their own intentions and ignore problems in their own workplaces. They write critical articles with the sole purpose of furthering their own performative professional goals of getting published, while they ignore possible avenues for change available to them as management educators (Spicer, Alvesson, and Kärreman 2009; Alvesson and Spicer 2016; Fleming and Banerjee 20I6). CMS scholars should admit that radical changes to management and organizational structures are unlikely, and long-standing operational cultures and norms persist even following systemic shocks like the financial crisis of 2008 (Spicer, Alvesson, and Kärreman 2009). Finally, some complain that CMS has focused on antiperformativity too literally misunderstanding the original meaning of this concept, and therefore stubbornly avoiding opportunities to engage with management and work toward change (Spicer, Alvesson, and Kärreman 2009; Fournier and Grey 2000; Wickert and Schaefer 2015). This last critique and the literature around it, along with its implications for academic libraries, are the focus of this article.

The answer to these shortcomings and contradictions, according to Spicer, Alvesson, and Kärreman, is for CMS to rethink its conception of and relationship to performativity (2009). Instead of being assiduously anti-performative, CMS should be "critically performative." This new understanding of performativity accommodates meaningful discursive interventions in organizational life and leads to incremental, but worthwhile progressive change (Spicer, Alvesson, and Kärreman 2009). Spicer, Alvesson, and Kärreman turn to theorists J. L. Austin and Judith Butler as models for critical performativity. Austin coined the term "performativity" in a series of lectures at Harvard University in 1955. In the decades since, the concept of performativity has rippled across the social science disciplines as a "radical travelling theory" (Austin 1962, Gond et al. 2016, 443). Austin offered the notion of performative utterances: speech acts that cannot be understood as true or false, but rather do things, such as a wedding vow ("I thee wed") or naming a ship $(1962,5)$. Performative utterances require "felicity": a "happy performative" relies on accepted convention, appropriate circumstances, correct execution, and alignment of intent (Austin 1962, I4-I5). Austin helped us to think about language as situated and bound in social context and norms, with important philosophical and ethical implications (McKinlay 20IO, I3I). Spicer, 
Alvesson, and Kärreman argue that Judith Butler's exploration of performativity in gender further helps us understand how discourses are made performative through repetition, subversion, and citations of previous performances $(2009,544)$. For Butler, gender is not "constative"-Austin's word for discourse that can be empirically proven true or false-but rather performative. Gender relies on social context, citation to pre-existing frameworks, and is a "signifying practice" (Butler I990, I45). For Butler, the process of discursive signification and the fact that identity is constituted rather than concrete or pre-determined offers the possibility of agency and empowerment (I47). Critical performativity in CMS argues for subversive and reconstitutive discursive interventions in management practice (Spicer, Alvesson, and Kärreman 2009, 544). While such actions would not necessarily result in radical change, they could lead to meaningful micro-emancipations for workers (Spicer, Alvesson, and Kärreman 2009).

Critical performativity - which some call the "third wave" of CMS - represents a gentler and more practical approach to CMS that actively locates space for incremental but meaningful progress (Spicer, Alvesson, and Kärreman 20I6, 225). After laying the theoretical ground, Spicer, Alvesson, and Kärreman outline a framework for CMS scholarship to move away from anti-performativity and instead embrace critical performativity. In their vision, critical performativity starts from a foundation of respect for management and appreciation of the context and constraints in which it operates $(2009,545)$. Critical performativity is caring, creates dialogue, and encourages reflection on the part of managers $(2009,545)$. They describe a critical performativity that embodies five main characteristics: affirmative stance, ethic of care, pragmatism, potentialities, and normative criteria $(2009,546)$. I will not elaborate on all of these characteristics here but will share some of their examples to deepen understanding. An affirmative stance would entail unearthing and affirming practitioner metaphors about organizations that encourage ambiguity or reflection instead of the deeply negative illustrations more typically used by CMS. For instance, critical performativity would describe organizations as "happy prisons" or "tragi-comedies," instead of "psychic prisons" or "discursive traps" (Spicer, Alvesson, and Kärreman 2009, 547). Ethic of care calls for CMS scholars to be less oppositional toward management, to affirm managers' voices while engaging them in open dialogue and pushing gently for change (Spicer, Alvesson, and Kärreman 2009, 548). Instead of seeking only to confirm well-established critical theories, CMS researchers should approach organizations led by a sense of mystery (Spicer, Alvesson, and Kärreman 2009, 549). "Potentialities" are envisioned as moving past a critique of organizations as they are and imagining what they could be, according to the Foucaultian concept of heterotopias-places and organizations that are very real and exist today, but where "normalization is temporarily short-circuited" (Spicer, 
Alvesson, and Kärreman 2009, 55I). In management, heterotopias can be found in cases of workplaces where "tempered radicalism" has taken hold, such as workerowned collaboratives (Spicer, Alvesson, and Kärreman 2009, 552).

In the decade since they first proposed critical performativity, Spicer, Alvesson, and Kärreman have revisited and refined their argument in response to their critics and advocates alike. In a follow-up 2016 publication, they narrow critical performativity to four primary themes or approaches: (I) focusing on issues that matter to a wider public, (2) dialectical reasoning that explores tensions, but leaves them unresolved, (3) forms of meaningful engagement, and (4) attending to the ultimate desired outcomes. For instance, CMS scholars that are critically performative would choose to study and publish on issues that matter to a wide public, such as media ethics, rather than limit their concerns to abstract theoretical debates that only ever matter to other CMS scholars (Spicer, Alvesson, and Kärreman 2016). To illustrate this approach, Alvesson writes about his own "critical performativity intervention," in which he published an article for a major Swedish newspaper accusing Sweden's public sector of focusing on superficial discourse and "looking good through window-dressing arrangements" as a way of coping with an oppressive regulatory apparatus $(2 \mathrm{O} 2 \mathrm{O}, 4)$. A critically performative CMS exploits those moments when current events create openings for even elite and powerful actors to rethink their practices, such as following a financial crisis or an environmental disaster (Spicer, Alvesson, and Kärreman 2016, 238). Critical performativity means that CMS scholars articulate alternatives to current practices by surfacing examples that are already happening at other organizations and foster actionable change in workplaces such as "bullshit reduction" (Spicer, Alvesson, and Kärreman 20I6, 240-42).

Wickert and Schaefer extend Spicer, Alvesson, and Kärreman's arguments by drawing attention to the actions of individuals, specifically micro-engagements with middle managers (2015). They use the term "progressive performativity" to imply an optimistic view of middle managers as potentially receptive to critical consciousness raising (2015, I09). For Wickert and Schaefer, Austin's concept of performativity means language affects what is seen, how it is seen, and how we take stock of our reality whereas Butler understood identity to be formed through small discursive acts that make space for subversion (Wickert and Schaefer 2015, II3-I4). Accordingly, the small speech acts of managers contain space for "reflexivity and processes of resignification and may ultimately trigger transformational change" (Wickert and Schaefer 2015, II5). Wickert and Schaefer propose micro-level engagement and reflexive conscientization as the means by which CMS researchers can reach managers and subversively promote progressive change (2015). Specifically, 
researchers engage managers in dialogue that "gently nudges" managers to reflect on their actions, the organization, and their own role (Wickert and Schaefer 2015, IO9).

Some CMS scholars accuse Spicer, Alvesson, and Kärreman of constructing critical performativity on shaky ground with a fundamental misunderstanding or misrepresentation of primary performativity theory. The "performativity" that Fournier and Grey are against derives from Lyotard (1984), who specifically refers to knowledge produced with means-end and performance in mind; Fournier and Grey's anti-performativity was never intended as a directive for CMS to disengage entirely from management practitioners and organizations (Gond et al. 2015, 445; Cantabous et al. 2016, I99-200). Accordingly, Spicer, Alvesson, and Kärreman's preoccupation with anti-performativity is misplaced. Spicer, Alvesson, and Kärreman claim to borrow from Butler as well as Austin, but neglect altogether Butler's concept of "iterability" - repeated, norms-based, highly regulated actsthrough which subjectivity is formed and which precedes language, and where the spaces for subversion of norms appear (Cantabous et al. 2016, 2OI-2). Butler's notion of resignification as a highly political act, enabling marginalized identities to challenge power by reappropriating discourse, is lost in the critical performativity literature (Butler 1997, 157-8; Cantabous et al. 2016, 202). By focusing on affirmative and practical discursive interventions with managers, Spicer, Alvesson, and Kärreman ignore everyday workers and neglect the political power of Butler's theory (2016, 202). Indeed, in their lack of theoretical rigor and dismissal of their critics, Spicer, Alvesson, and Kärreman inherently reject the political nature of performativity (Learmonth et al. 2016).

According to their critics, Spicer, Alvesson, and Kärreman's fundamental misreading of Austin and Butler undermines critical performativity's effectiveness. Instead, Cantabous, Gond, and other critics argue for deeper study of performativity and the ways it has been and could be applied to organizational and management theory. For instance, studying the social and discursive practices through which managers and organizations are performatively constituted as subjects might enable scholars to identify breakdowns in the constitutions of these identities that allow for intervention (Cantabous et al. 2016, 204). In response, Spicer, Alvesson, and Kärreman accuse their critics of obsession with fidelity to Butler and Austin, of "authoritarianism-a dogmatic faith to the ideas of a selected guru," while ignoring their core arguments or goals (2016, 230).

The other primary stream of criticism against Spicer, Alvesson, and Kärreman's vision of critical performativity is that it is inadequate, naive, and accommodationist. Perhaps the harshest of these judgments is that language alone is inadequate for challenging deeply ingrained capitalist systems (Fleming and Banerjee 20I6, 
258-9). Others argue that taken out of context, some of the discursive proposals of critical performativity - for instance, that vocalizing support for corporate social responsibility will ultimately lead to better behavior-are destined to fail. Successful performative utterances require appropriate contextual conditions that align with conventional expectations (Austin 1962, I4-I5). Indeed, there is evidence that managers exploit the dissonance between speech and action, and gratefully permit the speech act to stand in for meaningful action (Fleming and Banerjee 2016). Instead of focusing on bringing critical performativity to external organizations, therefore, CMS should focus its efforts on critical pedagogy in business schools, tend to inequities in universities (its own backyard), and create more public scholarship (Fleming and Banerjee 20I6). Indeed, it is inherently irrational for CMS scholars to ignore inequities and managerialism in their own workplaces while calling these out in the corporate sector (Cantabous et al. 2016, 2IO). Other critics of critical performativity look for a "middle ground" between total antagonism toward management and what they worry is Spicer, Alvesson, and Kärreman's simplistic accommodation of managerialism (Parker and Parker 20I7, I367). CMS scholars should look for alternatives that align with normative goals and organizations that are not only doing it right but also see mainstream organizations as adversaries: "It seems to us that what needs to be articulated are concrete instances of struggle by organizations, in effect, against other organizations" (Parker and Parker 2017, 1378).

\section{Critical Performativity in Library Organizations and Management}

Regardless of where one falls along the spectrum of critical performativity interpretation and debate, the critical performativity literature offers a robust foundation from which to explore implications for libraries and library managers. In proposing various discursive interventions into library management and organizations, I inherently align with the argument that one can remain critical, while still engaging with management, and actually make a meaningful difference. This article and my day-to-day work as a middle manager are themselves manifestations of the challenges and inherent contradictions of critical performativity. Rather than further explore these debates and interpretations or offer my own claims, I will simply move forward in the next section to consider potential avenues for critical library performativity. The discursive interventions I will focus on are those around which the various voices of critical performativity have found consensus: announcing ideals and intentions, identifying heterotopias, selection of issues and venues for scholarly focus, and desired outcomes grounded in normative values. 


\section{Announcing Ideals and Intentions}

Overall, critical performativity looks to the power of language to instigate progressive change. One way to achieve micro-emancipations is "to establish spaces in which new practices can be talked into existence" (Wickert and Schaefer 2015, II6). The theory behind this suggested practice is that progressive ideals are initially adopted aspirationally rather than materially by organizations, but are eventually accepted and ultimately integrated into practice because staff seek to avoid cognitive dissonance over time (Hack et al. 20I2). Another way discursive action is framed in critical performativity is through "applied communicative action" that brings interested staff into dialogue and debate (Spicer, Alvesson, and Kärreman 2009, 550). Wickert and Schaeder use the topic of corporate social responsibility (CSR) as an example of where language could be seen to be largely performative (for instance, claiming to be "green" or "community-driven" with little evidence or clarification), but by talking about social issues, managers and workers think about these more and ultimately change their behavior (2015). CMS scholars should reach out to middle managers responsible for CSR initiatives, such as sustainability or health and safety and engage in "reflexive conscientization" with them. This is an example of how progressive ideas can be "talked into existence" in organizations (Wickert and Schaefer 2015, I20).

In academic libraries, a fascinating case study for "announcing ideals and intentions" would be the issue of privacy for library users (Wickert and Schaefer 2015, II6). In recent years, this topic has been of growing concern for many library practitioners. Our professional discourse claims protection of library users' privacy as a core value (American Library Association 20I9). In the past, our actions mostly aligned with our discourse, for example in refusing to share information about circulation or library use and proudly opposing the Patriot Act in the United States (Drabinski 2006). However, as library use has dramatically transformed from printbased to digital, library practices have moved drastically out of alignment with our professional claims around privacy, which have not significantly evolved in years (Association of Research Libraries 2019).

Critical performativity's suggestion to speak ideals into existence is one way forward in the privacy arena that aligns with CMS goals and is critically performative, however it also requires acknowledgement and honest discussion about how far we currently fall short. Librarians publicly declare allegiance to progressive values that we regularly betray through our actions (Yousefi 20I7). For example, our professional declarations that we fully protect user privacy could be considered as an example of a failed performative: "The authority for speech to become action is contingent on the accumulation of a priori or reiterated practices" 
(Fleming and Banerjee 20I6, 264-5). To realize the power of critical performativity for making our privacy practices more ethical and protective of users, our performatives must acknowledge the true realities of our environment. Library use in a digital environment is far more trackable, and institutions are hungry for ever more data to prove their value (ARL 20I9; Nicholson, Pagowsky, and Seale 20I9). In response, a movement of library organizations, librarians, and scholars have begun shifting the discourse around user privacy to acknowledge complexity and change (Jones and Salo 20I8, Young et al.2019) At this time, statements of library privacy principles that are explicit about current privacy challenges while nonetheless stating aspirational intent can serve as authentic and successful discursive mechanisms toward ethical progress on privacy in libraries (NISO 2015, Stanford Libraries 2020).

My current experience co-leading a user privacy task force in my large research university library points to the tensions inherent in "announcing ideals and intentions." We have been working to draft consensus privacy principles around which we can align practices and communicate with our users. Our task force members have struggled with the same sort of contradictions referenced in the critical performativity literature: the principles to which we wish to adhere are not always reflected in our current practices, and in some cases might not be possible to achieve even if we diligently try. Often, we are hampered by the decisions of external vendors, upon whom we must rely for the services we need. This misalignment between principle and practice has created uncomfortable dissonance for our staff. As mentioned in the call for proposals for this special issue, the "growing chasm between our stated values and practices" is "ultimately alienating library workers" (Nicholson, Schmidt, and Slonowski 2019).

However, our task force experience also supports critical performativity's claim that progressive change can begin with dialogue and aspirational statements. In the process of revising and discussing our draft principles within my library, we have surfaced areas where we can easily make small but meaningful progress toward our stated principles. For instance, we can become better at notifying users of how their data is being used and we can make protection of user privacy a criterion for vendor negotiation and selection. The draft principles have sparked valuable conversation among library leadership about ways we can ethically participate in university learning analytics initiatives. The rational path forward seems to be the one that embraces ambiguity, is honest about difficult choices, and sustains meaningful discussion on the tradeoffs for our users. In this way, our collaborative and reflexive inquiry has been an example of critical performativity. 


\section{Heterotopias}

Critical performativity also proposes that critically-minded scholars and practitioners surface alternatives to mainstream management that can serve as models of progressive approaches. CMS has been "immobilized" by focusing on utopias (Spicer, Alvesson, and Kärreman 2009, 55I). Instead of utopias, critical performativity suggests that we find "heterotopias," a concept borrowed from Foucault (1986). In Foucault's work, heterotopias are "real places - places that do exist," unlike utopias which are purely imaginary, represent an ideal, and are impossibly perfect (Foucault 1986, 24). Interpretations and deployments of Foucault's theory are inconsistent and wide-ranging, but that does "not invalidate the...virtues of heterotopia as a theoretical tool" (Lees 1997, 8). Heterotopias exist outside of but are still related to and defined by existing spaces, and in this way are "spaces in which resistance and subversion occur, in which order is contested, inverted, and suspended" (Bazin and Naccache 2016, 226). In critical performativity, heterotopia as a theory means structures and approaches that sit alongside but offer alternatives to existing mainstream structures. "In a play of spatial ambiguities," write Beyes and Michels, "[heteropias] thus simultaneously reflect, incorporate and contest other sites" (2011, 523). Locating and calling attention to organizational heterotopias is a way for critical performativity scholars to "compare and contrast progressive practices from other empirical realities and in that way re-imagine future social arrangements" (Spicer, Alvesson, and Kärreman 20I6, 24I). CMS scholars should look for organizations that set themselves up in ways that oppose mainstream structures (Parker and Parker 20I7, I378). For instance, are there organizations that differentiate themselves from others in their sector by their ownership arrangements, flat management structures, or distinctly anti-capitalist goals?

In some ways, libraries are already heterotopic in their foundational concept and are also models of heterotopic practices. Indeed, libraries are one example Foucault uses, among many, to illustrate the concept of heterotopias (1986). Foucault saw libraries as heterotopic because they were static physical structures that were yet dedicated to "constituting a place of all times that is itself outside of time and inaccessible to its ravages" $(1986,26)$. Libraries are both finite and infinite, physical and virtual, buildings with limited capacity that also hold boundless knowledge (Radford, Radford, and Lingel 2015). They are full of contradictory co-existent tensions. They archive traditional heritage, democratize and revolutionize through information and free access, accept and accommodate capitalistic influence while promoting decidedly anti-commercial values (Lees 1997). Grand and successful library cooperatives such as interlibrary loan and innumerable library consortia could arguably be called heterotopic. These initiatives are widespread and taken for 
granted now, but in their creation represented radical departures from capitalistic competition. Through interlibrary loan and in their respective consortia, libraries work across institutional boundaries and cooperate to a degree that is generally unimaginable by any other unit in our own academic institutions. Empowered by these networks and supported by their processes and practices, libraries have established a distinct third space adjacent to but existing outside of our home institutions. These cooperative pursuits foster norms of openness and cooperation that permeate our profession and serve as models well beyond libraries.

Surveying the current library landscape, several organizational initiatives and movements surface as heterotopic. I would argue that the critical librarianship movement represents a heterotopia: a loose network of professionals who work within traditional institutions and connect through established venues, yet who cohere together apart from the mainstream in order to critique and subvert existing practices. A related movement is the Radical Reference collectives that deploy traditional library skills, such as research and reference support, in alignment with radical goals and operate as flat hierarchies (Radical Reference 2020). Another example of a heterotopia in libraries is the Library Freedom Project. This effort was started by librarian Alison Macrina to empower librarians to better educate themselves and their users around privacy issues (Macrina and Glaser 20I4). Through participation in the Library Freedom Institute and other Library Freedom Project initiatives, librarians are positioned to inform and subvert the existing privacy practices in their home institutions. Each of these heterotopias offer models we can study as alternatives to the usual ways of doing things; their very existence calls into question current taken-for-granted ways of doing things in our profession.

To dive even deeper, the We Here project richly illustrates how heterotopias simultaneously critique and help us imagine alternatives to existing structures. we here is a coalition of non-white librarians and archivists who have come together to fill gaps and address urgent problems related to the lack of diversity in the library profession. It is aligned with the library profession but adjacent to specific library organizations and mainstream professional associations. In this way, We Here represents a heterotopic structure that highlights and responds to shortcomings in the dominant reality: "Through our closed spaces, We Here is doing the work our institutions and organizations have not yet built into the fabric of our profession. We Here is helping to retain BIPOC [Black, Indigenous, and People of Color] in LIS professions" (We Here 2020). We Here has a web and social media presence, offers membership, private community spaces, professional development, and mentorship specifically for BIPOC library workers. It launched the We Here Community School where BIPOC library workers teach classes on a variety of topics, but always with 
acknowledgement of systemic racism and oppression. The We Here website states, "All of our events are either led by BIPOC or co-taught by BIPOC. This ensures that every education opportunity we offer is taught from the perspective that recognizes systemic racism and discrimination" (2020).

\section{Issue and Venue Selection}

In addition to highlighting existing alternatives to mainstream practices, critical performativity also advocates focusing on issues that truly matter to practising managers and talking directly about these in accessible channels (i.e., not just scholarly journals). For too long, according to the critical performativity argument, CMS has engaged in arcane and highly theoretical debates that are removed from the very real issues facing managers and also absent from any conversation in which one could hope to reach them. "By building a thought world around a small selection of theoretical texts, the would-be critic often generates a kind of symbolic radicalism," write Spicer, Alvesson, and Kärreman (2016, 23I). Critical performativity adherents should ask themselves two questions: first, is the issue of wide public importance and second, is there an opening to question the public's taken-for-granted assumptions about this issue (Spicer, Alvesson, and Kärreman 2016, 234)? For instance, the 2008 financial crisis and the ongoing public debate around media ethics are topics Spicer, Alvesson, and Kärreman suggest are ideal for CMS scholars to publicly engage (2016, 234).

The 2020 coronavirus pandemic that is currently gripping the world is surely an example of what critical performativity scholars mean by a topic of public importance with potential for critical discursive interventions. While still in the early days as I write this article, this crisis has already surfaced inherent contradictions in academic libraries' roles and functions on their campuses. These exemplify irrationality: libraries are so essential during these expansive closures that staff must still keep them open, but they are also typically subject to budget cuts year after year because they do not bring in tuition or grant revenue. Inequities in our professional labour circumstances are also stark at this moment, with faculty librarians from research universities allowed and able to continue their work and earn their salaries from home while public librarians, especially clerical workers, have been almost immediately laid off (Solon 202O; also see \#ProtectLibraryWorkers on Twitter). Spicer, Alvesson, and Kärreman argue that critics should take on issues of public importance not by building up more evidence and facts but by asking reflexive, rather than instrumental, questions that challenge assumptions (2016, 235). At a moment when precarity and safety are top of mind, critically-minded scholars should open these thoughtful, challenging conversations in channels that managers are likely to 
engage with. In this case, that might mean questioning how we rank and respond to stakeholders or defend our value, for example, whether continuing curbside checkout for community members matters more than life-or-death safety for precarious staff required to be on site.

\section{Desired Outcomes}

CMS has valuable abstract ideals, like equality and justice, but rarely translates these to real desired outcomes. Critical performativity proponents argue that CMS scholars should work to achieve several tangible outcomes that are in service of these ideals (Spicer, Alvesson, and Kärreman 20I6). For instance, Spicer, Alvesson, and Kärreman suggest a "desired outcome" is "bullshit reduction" (2016, 240). They argue that business schools are "veritable junkyards filled with the ideological wreckage of long discredited ideas" and that "companies are even worse" (20I6, 24I). Managers, anxious and insecure in their own positions, are pushed to experiment with fads rather than enact meaningful change that responds to real problems. Their examples of bullshit in mainstream management will ring familiar to library workers: structural racism that is met with ever more diversity training, persistent labour shortages that are responded to again and again by disruptive reorganizations but never more staff, and performance declines (in positivist measures such as sales or profits) that lead only to the hiring of more consultants (20I6, 24I).

Critical librarian-scholars can call out bullshit in our field. Library management also suffers from this same long history of embracing superficial fads from mainstream management and applying these to our organizations, even though as educational institutions, our purpose and challenges are nothing like the for-profit sector (Leebaw 2019). In her 2018 conference keynote address, Schmidt suggests that bullshit surfaces in myriad ways in academic libraries: in the form of claims that libraries are neutral, in the way our profession fetishizes leaders, through tone policing that silences legitimate dissent, indecisiveness over our identity, and negligence of our fiscal responsibilities. Another example can be found in the way that academic libraries uncritically frame the practice of hiring external consultants to aid in reorganizations and strategic planning as neutral and positive, even though workers often experience this phenomenon as disempowering and disillusioning (Dymarz and Harrington 2019). Other critical librarian-scholars point out how problematic it is for libraries to adopt capitalist discourse and frame our patrons as consumers (Day 2002; Nicholson 2015). The discourse around innovation is particularly prevalent and problematic for academic libraries (Nicholson 2015; Schmidt 20I8). Instead of talking about our value in terms of return on investment, transactions with students, and measurable outputs, we should reflect on how our 
work in academic libraries "contribute[s] to making higher education a transformative experience, a frame in which quality is value added" (Nicholson 2015, 334).

\section{Conclusion}

Critical librarian-scholars are more practised than our critical management studies counterparts in balancing and integrating critical perspectives into our daily professional practice. As scholars and practitioners alike, we are accustomed to weaving our way through the contradictions, worries of hypocrisy, or sense of futility that we experience at times. I am intrigued by critical performativity because it provides guidance for navigating this path authentically and usefully. CMS as a body of literature holds relevance and value for academic library managers because it can help us question the assumptions that underlie our management practices, such as the focus on improving performance and metrics and the solely positivist, rational methods. CMS brought the voice of workers to management studies and questioned the management project itself. Critical performativity is the latest wave of CMS, one that preserves many of the goals and ideals of CMS but seeks greater engagement with management practitioners and smaller wins, through micro-emancipations of workers. Its own adherents worry that CMS will have failed in its ultimate goals if it does not lead to real change in organizations. In order to influence everyday management practice, critical performativity turns to performative theorists like Austin and Butler to argue for discursive interventions that subvert and undermine mainstream approaches. Is critical performativity enough to enact real change in management? Can one truly be critical and also participate in mainstream organizations? There is not a clear answer to this enormous question, but critical performativity would urge us to debate and dialogue it nonetheless.

In this paper, I have engaged in this conversation by exploring some ways critical performativity might be deployed in library management and organizational practices. Critical library performativity means aligning our practices more closely with our deepest held professional values, such as user privacy. Library managers can take notice of the heterotopic projects that have been created as alternatives alongside our mainstream structures, signifiers of where we are falling short with tangible ideas for how to do better. Critical librarian-scholars can influence mainstream management practices by focusing on urgent issues of public importance, such as the coronavirus crisis, and asking reflexive questions that challenge assumptions. Finally, we can reject capitalist discourse and management fads when these are brought into our profession. While these various suggestions may indeed fall short, critical performativity offers rich and intriguing ideas for a critical library management praxis 


\section{ABOUT THE AUTHOR}

Danya Leebaw leads a department of social science and professional program liaison librarians at the University of Minnesota Libraries. Prior to assuming this role, Danya was a social sciences librarian at Carleton College and a business librarian at Emory University. She earned her M.L.I.S. at the University of Pittsburgh and a B.A. in History from Grinnell College. She worked in advertising for nearly a decade before becoming a librarian. Her research entails critical inquiries into labour and management issues in academic libraries, including academic freedom for librarians and critical management studies.

\section{REFERENCES}

Alvesson, Mats. 2020. "Critical Performativity in Practice: The Chronicle as a Vehicle for Achieving Social Impact." European Journal of Work and Organizational Psychology (Volume, Issue not yet available): I-8 https://doi.org/IO.IO80/I359432X.2020.I739744.

Alvesson, Mats, and Hugh Willmott, eds. 1992. Critical Management Studies. London: Sage.

_-_. 2012. Making Sense of Management: A Critical Introduction. London: Sage.

Alvesson, Mats, and André Spicer. 20I6. "(Un)Conditional Surrender? Why Do Professionals Willingly Comply with Managerialism." Journal of Organizational Change Management 29(I): 29-45. https://doi. org/IO.IIO8/JOCM-II-2OI5-O22I

American Library Association. "Privacy: An Interpretation of the Library Bill of Rights." Revised June 20I9. http://www.ala.org/advocacy/intfreedom/librarybill/interpretations/privacy.

Association of Research Libraries. 2019. "Research Library Issues, No. 297 (2019): The Current Privacy Landscape." Research Library Issues. Washington, D.C. https://doi.org/IO.29242/rli.297

Austin, J.L. 1962. How to Do Things with Words. Cambridge, MA: Harvard University Press.

Bazin, Yoann, and Philippe Naccache. 2016. "The Emergence of Heterotopia as a Heuristic Concept to Study Organization." European Management Review I3, no. 3: 225-33. https://doi.org/IO.IIII/emre.I2082

Beyes, Timon, and Christoph Michels. 20II. "The Production of Educational Space: Heterotopia and the Business University." Management Learning 42, no. 5: 52I-36. https://doi.org/IO.II77/I3505076II40000I

Butler, Judith. 1990. Gender Trouble: Feminism and the Subversion of Identity. New York: Routledge.

- - 1997. Excitable Speech: A Politics of the Performative. New York: Routledge.

Cabantous, Laure, Jean-Pascal Gond, Nancy Harding, and Mark Learmonth. 2016. "Critical Essay: Reconsidering Critical Performativity." Human Relations 69, no. 2: 197-213. https://doi. org/IO.II77/ool8726715584690

Day, Mark T. 2002. "Discourse Fashions in Library Administration and Information Management: A Critical History and Bibliometric Analysis." Advances in Librarianship 26: 23I-98.

Drabinski, Emily. 2006. "Librarians and the Patriot Act." The Radical Teacher 77: I2-I4. https://www.jstor. org/stable/20710376

Dymarz, Ania, and Marni Harrington. 2019. "Consultants in Canadian Academic Libraries: Adding New Voices to the Story." In the Library with the Lead Pipe. http://www.inthelibrarywiththeleadpipe. org/2019/consultants/

Fleming, Peter, and Subhabrata Bobby Banerjee. 2016. "When Performativity Fails: Implications for Critical Management Studies.” Human Relations 69, no. 2: 257-76. https://doi. org/IO.II77/ool872671559924I

Foucault, Michel. 1986. "Of Other Spaces." Translated by Jay Miskowiec. Diacritics I6, no. I: 22-27. https:// doi.org/I0.2307/464648

Fournier, Valerie, and Chris Grey. 200o. "At the Critical Moment: Conditions and Prospects for Critical Management Studies." Human Relations 53, no. I: 7-32. 
Gond, Jean-Pascal, Laure Cabantous, Nancy Harding, and Mark Learmonth. 2016. "What Do We Mean by Performativity in Organizational and Management Theory? The Uses and Abuses of Performativity." International Journal of Management Reviews I8: 440-63. https://oi-org/IO.III/ ijmr.I2074.

Jones, Kyle, and Dorothea Salo. 2018. "Learning Analytics and the Academic Library: Professional Ethics Commitments at a Crossroads." College \& Research Libraries 79, no. 3: 304-23. https://doi. org/I0.5860/crl.79.3.304

Learmonth, Mark, Nancy Harding, Jean-Pascal Gond, and Laure Cabantous. 20I6. "Moving Critical Performativity Forward." Human Relations 69, no.2: 25I-56. https://doi.org/IO.II77/ooI8726715620477

Leebaw, Danya. 2019. "Participatory and Ethical Strategic Planning: What Academic Libraries Can Learn from Critical Management Studies." Library Trends 68, no. 2: IIO-I29. http://doi.org/IO.I353/ lib.2019.0033.

Lees, Loretta. 1997. "Ageographia, Heterotopia, and Vancouver's New Public Library." Environment and Planning D: Society and Space I5, no. 3: 32I-47. https://doi.org/IO.IO68/dI5032I

Lyotard, J-F. 1984. The Postmodern Condition. Manchester: Manchester University Press.

Macrina, Alison, and April Glaser. 20I4. "Radical Librarianship: How Ninja Librarians Are Ensuring Patrons' Electronic Privacy." Boing Boing (blog). September I3, 2014. https://boingboing. net/20I4/o9/13/radical-librarianship-how-nin.html

McKinlay, Alan. "Performativity: From J. L. Austin to Judith Butler." In "The Leading Journal in the Field": Destabilizing Authority in the Social Sciences of Management, edited by Peter Armstrong and Geoff Lightfoot, II9-42. London, UK: MayFlyBooks, 2010.

Nicholson, Karen P. 2015. "The McDonaldization of Academic Libraries and the Values of Transformational Change." College \& Research Libraries 76, no. 3: 328-38. https://doi.org/I0.5860/ crl.76.3.328

Nicholson, Karen P., Nicole Pagowsky, and Maura Seale. 2019. "Just-in-Time or Just-in-Case? Time, Learning Analytics, and the Academic Library." Library Trends 68 (I): 54-75. https://doi.org/IO.I353/ lib.2019.0030

Nicholson, Karen, Jane Schmidt, and Lisa Sloniowski. 20I9. "CFP: CJAL Special Issue: Academic Libraries and the Irrational." https://cjal.ca/index.php/capal/announcement/view/7I9

NISO. “NISO Consensus Principles on User's Digital Privacy in Library, Publisher, and SoftwareProvider Systems (NISO Privacy Principles).” Published December IO, 2015. https://groups.niso.org/ apps/group_public/download.php/I6064/NISOPrivacyPrinciples.pdf

Parker, Simon, and Martin Parker. 20I7. "Antagonism, Accommodation and Agonism in Critical Management Studies: Alternative Organizations as Allies." Human Relations 70, no. II: I366-87. https://doi.org/IO.II77/OoI8726717696I35

Radical Reference. 2012. "About Us." Accessed April I4, 2020. https://radicalreference.info/about

Radford, Gary P., Marie L. Radford, and Jessica Lingel. 2015. "The Library as Heterotopia: Michel Foucault and the Experience of Library Space." Journal of Documentation 7I, no. 4: 733-5I. https://doi. org/IO.IIO8/JD-OI-20I4-0006

Reynolds, Michael. 1999. "Critical Reflection and Management Education: Rehabilitating Less Hierarchical Approaches." Journal of Management Education 23, no. 5: 537-53.

Schmidt, Jane. "Innovate This! Bullshit in Academic Libraries and What We Can Do about It." Keynote presented at the CAPALI8 conference, University of Regina, Saskatchewan, 29 May, 20I8. https:// digital.library.ryerson.ca/islandora/object/RULA\%3A7II3

Schroeder, Robert, and Christopher V. Hollister. 2014. "Librarians' Views on Critical Theories and Critical Practices." Behavioral \& Social Sciences Librarian 33, no. 2: 9I-II9. https://doi.org/I0.I080/016392 69.20I4.912104 
Solon, Olivia. "Library Workers Fight for Safer Working Conditions amid Coronavirus Pandemic." NBC News, April 8, 2020. https://www.nbcnews.com/news/us-news/library-workers-fight-saferworking-conditions-amid-coronavirus-pandemic-nII79346

Spicer, André, Mats Alvesson, and Dan Kärreman. 2009. "Critical Performativity: The Unfinished Business of Critical Management Studies." Human Relations 62, no.4: 537-60. https://doi. org/IO.II77/OoI8726708IOI984

- - 20I6. "Extending Critical Performativity." Human Relations 69, no. 2: 225-49. https://doi. org/IO.II77/OoI8726715614073

Stanford Libraries. "Statement on Patron Privacy and Database Access." Accessed April I4, 2020. https://library.stanford.edu/using/special-policies/statement-patron-privacy-and-database-access

We Here. Accessed October 2, 2020. https://www.wehere.space/

Wickert, Christopher, and Stephan M. Schaefer. 2015. "Towards a Progressive Understanding of Performativity in Critical Management Studies." Human Relations 68, no. I: IO7-30. https://doi. org/IO.II77/ool8726713519279

Young, Scott W. H., Jason A. Clark, Sara Mannheimer, and Lisa Janicke Hinchliffe. 2019. "A Roadmap for Achieving Privacy in the Age of Analytics: A White Paper from A National Forum on Web Privacy and Web Analytics." Montana State University. https://doi.org/IO.15788/201904I6.15445

Yousefi, Baharak. 20I7. "On the Disparity Between What We Say and What We Do in Libraries." In Feminists Among Us: Resistance and Advocacy in Library Leadership, edited by Baharak Yousefi and Shirley Lew, 9I-IO5. https://summit.sfu.ca/item/17387 